\title{
Development and Evaluation of a Dot Blot Analysis for the Detection of White Spot Syndrome Baculovirus (WSBV) in Penaeus monodon
}

\author{
Poh-Shing Chang*, Dong-Hung Tasi and Yu-Chi Wang \\ Department of Aquaculture, National Kaohsiung Institute of Marine Technology Kaohsiung, Taiwan, R.O.C.
}

(Received December 15, 1997)

\begin{abstract}
Three batches of Penaeus monodon (total of 66 shrimp) were tested for the presence of WSBV by 2-step PCR, in situ hybridization and dot blot analysis using a nucleic acid probe. The results of in situ hybridization and 2-step PCR were consistent and used as the standard for comparison. Except for a low number of false negatives, results of dot blot using either DNA or tissue homogenate from the gill, pleopod, eyestalk and hemolymph paralleled the results of 2-step PCR and in situ hybridization. A quick dot blot analysis was also developed, which took only $4-4.5 \mathrm{~h}$ to produce results. We conclude that dot blotting using tissue homogenate from the eyestalk provides a rapid, cost effective and convenient diagnostic method for WSBV detection in the field and for screening $P$. monodon broodstock.
\end{abstract}

Key words: white spot syndrome baculovirus, WSBV, Penaeus monodon, dot blot, diagnosis

The significance of molecular based diagnostic techniques to disease management in aquaculture is rapidly growing. Both nucleic acid probes (chemically labelled DNA fragments that hybridize to homologous target DNA) and polymerase chain reaction (amplification of selected DNA sequences) are powerful diagnostic tools for the identification of pathogens, and they provide rapid and accurate results in disease diagnosis (Lightner et al., 1992; Mialhe et al., 1992; Vivares and Guesdon, 1992). In shrimp aquaculture, the white spot syndrome baculovirus (WSBV) which has been found in many shrimp species in Asian countries has had a significant negative impact on the shrimp farming industry by causing substantial production and economic losses (Chou et al., 1995; Wang et al., 1995; Lightner, 1996). Recently, 2-step PCR and an in situ hybridization technique were developed to diagnose WSBV infection (Chang et al., 1996; Lo et al., 1996a).

In Taiwan, most of the broodstock of Penaeus monodon for seed production are captured from the wild population in the coastal waters around southern Taiwan (Chen 1990). However, the prevalence of WSBV has been shown to be high in these wild brooders (Lo et al., 1997), and once captured, even uninfected brooders are liable to be exposed to the virus. For example, it has now been shown that some of the wild decapods which are used as feed for the broodstock are also susceptible to WSBV infection (Lo et al., 1996b; Chang et al., 1998; Wang et al., 1998). Although there is still no direct evidence that WSBV in broodstock can be vertically transmitted to their offspring from an infected ova, some WSBV-infected spawners do infact produce WSBVpositive larvae (Lo et al., 1997).

Screening to produce specific pathogen-free (SPF) broodstock is now one important strategy for viral disease control in shrimp aquaculture (Wyban et al., 1992). For this to be practicable in commercial hatchery farms, however, non-lethal, easier, more cost effective and more convenient diagnostic methods need to be developed and applied. The two currently preferred methods of WSBV detection, in situ hybridization and 2-step PCR, are time-consuming and require access to standard histological laboratory equipment or a PCR machine (Thermal Cycler). In the present study, a dot blot hybridization assay using either a tissue homogenate or extracted DNA was compared with PCR and in situ hybridization with respect to both sensitivity and specificity, and an attempt was also made to develop of a quick dot blot hybridization method. Differences in cost, convenience and accuracy are also discussed.

\footnotetext{
* E-mail: pschang@mail.nkimt.edu.tw
} 


\section{Materials and Methods}

\section{Shrimp}

This study investigated $P$. monodon (10-15 g) collected from Kaohsiung in Taiwan between July and August, 1997. Ten shrimp were randomly collected from culture farm A on July 8, 1997 during an outbreak of white spot disease. Eleven other shrimp were randomly collected from culture farm B on July 20, 1997 at a time when mild white spot syndrome could be found in this farm's shrimp population. Apparently healthy shrimps were obtained from a third culture farm on Aug. 5, 1997. Random samples taken from this group were confirmed to be WSBV-free by in situ hybridization and 2-step PCR analysis.

\section{Artificial infection}

In order to obtain shrimp with different WSBV infection, an artificial infection test was carried out. The healthy shrimps were divided into nine groups with 10 shrimp in each group and kept in $50 l$ plastic tanks containing seawater (salinity $=20 \mathrm{ppt}$ ) at ambient temperature (approximately 28 to $30^{\circ} \mathrm{C}$ ). Shrimp in six of these groups (S1-S6) were bathed in $5 l$ seawater containing $50 \mathrm{~m} l$ virus stock solution for $2 \mathrm{~h}$ and then rinsed with clean seawater before stocking to $50 l$ tanks. The virus stock solution was prepared as following: $5 \mathrm{~g}$ of gills, muscle and cuticular epidermis from the naturally infected shrimp were removed, ground into pieces, and $50 \mathrm{~m} l$ of cold 20 ppt seawater was added; the mixtures were centrifuged at $850 \times \mathrm{g}$ for $10 \mathrm{~min}$ and the supernatant fluid was used as virus stock solution. The shrimp in other three groups $(\mathrm{C} 1-\mathrm{C} 3)$ were bath in sea water and served as negative controls. One shrimp from each group was sampled at $0,20,45,68$ and $96 \mathrm{~h}$ post-infection (pi).

\section{Hemolymph collection}

Hemolymph $(0.1-0.3 \mathrm{ml})$ was collected aseptically from the ventral sinus of each shrimp using a 26-gauge needle and a $1.0 \mathrm{ml}$ syringe. Prior to collecting the hemolymph samples, the hub of each needle was filled with $1.0 \%$ sodium citrate solution to prevent coaggulation. These hemolymph samples were stored at $-20^{\circ} \mathrm{C}$ until used for dot blot analysis.

\section{Tissue homogenization and DNA extraction}

The pleopods, gills and eyestalks (approx. $50 \mathrm{mg}$; eyeballs were removed from eyestalks) were removed aseptically from the shrimp and placed in labeled $1.5 \mathrm{ml}$ eppendorf tubes with $500 \mu l$ digestion buffer $(100 \mathrm{mM}$ $\mathrm{NaCl}, 10 \mathrm{mM}$ Tris-HCl, pH8, 25 mM EDTA, pH8, 0.5\% sodium dodecyl sulfate, $0.1 \mathrm{mg} / \mathrm{m} l$ proteinase $\mathrm{K}$ ). The samples were chilled on ice and crushed with a disposable stick. Ten $\mathrm{ml}$ of tissue homogenate were removed to another $1.5 \mathrm{ml}$ eppendorf tube and stored at $-20^{\circ} \mathrm{C}$ until used for dot blot analysis. DNA was isolated from remaining tissue homogenate according to the method described by Lo et al. (1996a) with some modification. Briefly, the tissue homogenate was incubated at $65^{\circ} \mathrm{C}$ for $1 \mathrm{~h}$, and successively extracted with $1 \mathrm{X}$ volume of phenol twice and $1 \mathrm{X}$ volume chloroform/isoamylalcohol once. The DNA was precipitated by $2 \mathrm{X}$ volumes of cold absolute ethanol, dried and redissolved in $0.1 \mathrm{X}$ TE buffer ( $1 \mathrm{mM}$ Tris, $0.1 \mathrm{mM}$ EDTA, pH 7.6) at $65^{\circ} \mathrm{C}$ for $15 \mathrm{~min}$. The extracted DNA was stored at $-20^{\circ} \mathrm{C}$ until used in dot blot and PCR analysis.

\section{Dot blot analysis for WSBV infection}

An insert of recombinant plasmid pms146 (1447 bp) selected from the WSBV Sal I genomic library was used for the preparation of the DNA probe used in the dot blot analysis (Chang et al., 1996; Lo et al., 1996a). The hemolymph, extracted DNA and homogeneous tissue fluid were boiled for $10 \mathrm{~min}$ and quickly chilled on ice. A $1 \mu l$ volume of each sample was then applied to Nylon1 membrane (GIBCO BRL Life Technologies, Grand Island, NY, USA). The blots were air-dried and baked at $80^{\circ} \mathrm{C}$ for $30 \mathrm{~min}$ and crosslinked for $2 \mathrm{~min}$ by UV light. After prehybridization at $37^{\circ} \mathrm{C}$ for $2 \mathrm{~h}$ in hybridization solution [ $50 \%$ formamide, $5 \mathrm{X}$ Denhard's reagent, $0.1 \%$ Ficoll $400,0.1 \%$ polyvinyl pyrrolidone, $0.1 \%$ bovine serum albumin (BSA), 5X standard saline citrate (SSC; $1 \mathrm{X} \mathrm{SSC}=0.15 \mathrm{M} \mathrm{NaCl}, 0.015 \mathrm{M}$ tri-sodium citrate, (pH 7.0), $50 \mathrm{mM}$ Tris- $\mathrm{HCl}(\mathrm{pH} \mathrm{8.0),} 1 \mathrm{mM}$ EDTA)], the blots were hybridized at $37^{\circ} \mathrm{C}$ for $16-18 \mathrm{~h}$ with hybridization solution containing $10 \mathrm{ng} / \mathrm{m} l$ digoxigenin (DIG)-labeled probe. Subsequent steps were carried out using a DIG DNA Detection Kit following instructions provided by the manufacture (Boehringer, Mannheim). The results were read following a $1 \mathrm{~h}$ development period and again after $2 \mathrm{~h}$ and $4 \mathrm{~h}$ further development.

\section{One-step PCR analysis for WSBV infection}

The oligonucleotide primers $146 \mathrm{~F} 1$ and $146 \mathrm{R} 1$ were used for 1-step amplification of a WSBV DNA fragment (Lo et al., 1996b). The DNA samples extracted from the pleopod, gill and eyestalk were used as template DNA. The PCR amplification procedure was 
based on the method described by Lo et al. (1996b) with some modification. The reaction mixture contained 0.1 $\mu \mathrm{g}$ template DNA, $100 \mathrm{pmol}$ of each primer, $200 \mu \mathrm{M}$ of each deoxynucleotide triphosphate, $10 \mathrm{mM}$ Tris- $\mathrm{HCl}$, pH 8.8, $50 \mathrm{mM} \mathrm{KCl}, 1.5 \mathrm{mM} \mathrm{MgCl}_{2}, 0.1 \%$ Triton $\mathrm{X}-100$ and 2 units of DynaZyme ${ }^{\mathrm{TM}}$ DNA Polymerase (Finnzymes Oy, Riihitontuntie 14 B, FIN-02200 Espoo, Finland). The reaction was performed for 40 cycles in an automatic thermal cycler (AG-9600 Thermal Station, Biotronics Corp. Lowell, MA, USA) programmed for $1 \mathrm{~min}$ at $94^{\circ} \mathrm{C}, 1 \mathrm{~min}$ at $55^{\circ} \mathrm{C}$ and $2 \mathrm{~min}$ at $72^{\circ} \mathrm{C}$ followed by a $5 \mathrm{~min}$ extension at $72^{\circ} \mathrm{C}$ after the last cycle. Negative control reactions containing no DNA template were run for all PCR reactions. Ten $\mu l$ of each PCR product was analyzed by electrophoresis in $1 \%$ agarose gels containing $0.5 \mathrm{mg} / \mathrm{m} l$ ethidium bromide and visualized by ultraviolet transillumination.

\section{Two-step PCR analysis for WSBV infection}

Ten $\mu l$ of 1-step PCR product was added to $90 \mu l$ of reaction mixture (as described above) contaning the primers 146F2 and 146R2 (Lo et al., 1996b). After the same 40 amplification cycles, the PCR products were analyzed on $1 \%$ agarose gels as described above.

\section{In situ hybridization analysis for WSBV infection}

Gills and pleopods were excised and fixed in neutral buffered formalin solution ( $10 \%$ formalin, $33 \mathrm{mM}$
$\mathrm{NaH}_{2} \mathrm{PO}_{4}, 45 \mathrm{mM} \mathrm{Na}_{2} \mathrm{HPO}_{4}$ ). The fixed tissues were embedded and sectioned at $5 \mu \mathrm{m}$ using standard histological procedures (Bell and Lightner, 1988). Duplicate sections were made for both hematoxylin and eosin staining and for corresponding in situ hybridization with the digoxigenin-labeled probe. Detection of WSBV infection by in situ hybridization was based on the method described by Chang et al. (1996) with some modification. Briefly, the tissues were deparaffinized and rehydrated, followed by digestion with proteinase $\mathrm{K}(100 \mu \mathrm{g} / \mathrm{m} l)$ for $15 \mathrm{~min}$ and postfixation in $4 \%$ paraformaldehyde for $10 \mathrm{~min}$. After prehybridization, the sections were hybridized at $37^{\circ} \mathrm{C}$ for $16 \mathrm{~h}$ in hybridization solution containing $10 \mathrm{ng} / \mathrm{ml}$ DNA probe. A DIG Detection Kit (Boehringer Mannheim) was then used to identify viral DNA. After development for $2 \mathrm{~h}$ and $24 \mathrm{~h}$, WSBV infected cells were indicated by the presence of blue to dark purple precipitates.

\section{Development of a quick dot blot protocol}

In an attempt to simplify and shorten the dot blot analysis procedure, serially 10 -fold diluted $\left(10^{-3}\right.$ to $\left.10^{-7}\right)$ 1 step WSBV positive PCR products were applied to Nylon-1 membranes and used in a battery of dot blot tests. The dot blot procedure described earlier was used as the positive control reference standard (Table 1, column 1), while modifications to this standard procedure are detailed in Table 1, columns 2-14.

Table 1. Standard dot blot analysis (control; column 1) and other modified procedures (columns 2-14). The results at the foot of each column show the highest serial dilution that gives a positive results

\begin{tabular}{|c|c|c|c|c|c|c|c|c|c|c|c|c|c|c|}
\hline $\begin{array}{c}\text { Procedure } \\
\text { Number }\end{array}$ & 1 & 2 & 3 & 4 & 5 & 6 & 7 & 8 & 9 & 10 & 11 & 12 & 13 & 14 \\
\hline \multicolumn{15}{|l|}{ Dot Blot Steps } \\
\hline Baking (min) & 30 & 15 & 0 & 30 & 30 & 30 & 30 & 30 & 30 & 30 & 30 & 30 & 30 & 30 \\
\hline UV Cross Linkage (min) & 2 & 2 & 2 & 0 & 2 & 2 & 2 & 2 & 2 & 2 & 2 & 2 & 2 & 2 \\
\hline Prehybridization (h) & 2 & 2 & 2 & 2 & $1 / 2$ & $1 / 4$ & 2 & 2 & 2 & 2 & 2 & 2 & 2 & 2 \\
\hline $\begin{array}{l}\text { Hybridization } \\
\text { Washing (min) }\end{array}$ & $\mathrm{O} / \mathrm{N}^{\mathrm{c}}$ & $\mathrm{O} / \mathrm{N}$ & $\mathrm{O} / \mathrm{N}$ & $\mathrm{O} / \mathrm{N}$ & $\mathrm{O} / \mathrm{N}$ & $\mathrm{O} / \mathrm{N}$ & $2 \mathrm{~h}$ & $30 \mathrm{~m}$ & $\mathrm{O} / \mathrm{N}$ & $\mathrm{O} / \mathrm{N}$ & $\mathrm{O} / \mathrm{N}$ & $\mathrm{O} / \mathrm{N}$ & $\mathrm{O} / \mathrm{N}$ & $\mathrm{O} / \mathrm{N}$ \\
\hline $2 \mathrm{XSSC}^{\mathrm{a}}$ & 30 & 30 & 30 & 30 & 30 & 30 & 30 & 30 & 10 & 5 & 30 & 30 & 30 & 30 \\
\hline 1XSSC & 30 & 30 & 30 & 30 & 30 & 30 & 30 & 30 & 10 & 5 & 30 & 30 & 30 & 30 \\
\hline $0.5 \mathrm{XSSC}$ & 30 & 30 & 30 & 30 & 30 & 30 & 30 & 30 & 10 & 5 & 30 & 30 & 30 & 30 \\
\hline $0.5 \mathrm{XSSC}$ & 30 & 30 & 30 & 30 & 30 & 30 & 30 & 30 & 10 & 5 & 30 & 30 & 30 & 30 \\
\hline Blocking (min) & 30 & 30 & 30 & 30 & 30 & 30 & 30 & 30 & 30 & 30 & 15 & 30 & 30 & 30 \\
\hline Conjugation (min) & 30 & 30 & 30 & 30 & 30 & 30 & 30 & 30 & 30 & 30 & 30 & 15 & 30 & 30 \\
\hline Washing (min) & 15 & 15 & 15 & 15 & 15 & 15 & 15 & 15 & 15 & 15 & 15 & 15 & 10 & 5 \\
\hline $2 \%$ Tween 20 in Buf $I^{b}$ & $2 \mathrm{X}$ & $2 \mathrm{X}$ & $2 \mathrm{X}$ & $2 \mathrm{X}$ & $2 \mathrm{X}$ & $2 \mathrm{X}$ & $2 \mathrm{X}$ & $2 \mathrm{X}$ & $2 X$ & $2 \mathrm{X}$ & $2 \mathrm{X}$ & $2 \mathrm{X}$ & $2 X$ & $2 X$ \\
\hline Results & $10^{-7}$ & $10^{-7}$ & $10^{-7}$ & $10^{-6}$ & $10^{-7}$ & $10^{-7}$ & $10^{-7}$ & $10^{-6}$ & $10^{-7}$ & $10^{-7}$ & $10^{-7}$ & $10^{-7}$ & $10^{-7}$ & $10^{-7}$ \\
\hline
\end{tabular}

a: $1 \mathrm{X} \mathrm{SSC}=0.15 \mathrm{M} \mathrm{NaCl}, 0.015 \mathrm{M}$ tri-sodium citrate, $\mathrm{pH} 7.0$

b: Buf I = $100 \mathrm{mM}$ Tris- $\mathrm{HCl}, 150 \mathrm{mM} \mathrm{NaCl}, \mathrm{pH} 7.5$

c: $\mathrm{O} / \mathrm{N}$ : overnight $(16-18 \mathrm{~h})$ 


\section{Results}

\section{Dot blot analysis}

Figure 1 shows the typical results of dot blot using DNA (A) and tissue homogenate (B) with positive (P) and negative $(\mathrm{N})$ controls. The dark purple dots (using DNA) or those with a dark purple ring around the dot (using tissue homogenate) are WSBV-positive (Fig. 1, Nos. 1, 4, 5, 6, 9, 11 and 12).

\section{Detection of WSBV in shrimp from farm $A$}

Of the ten shrimp sampled from farm A just after an outbreak of white spot disease, 6 shrimp showed clear evidence of white spot syndrome while 4 shrimp were asymptomatic. All the dot blot results using extracted DNA and tissue homogenate from the gill, pleopod and eyestalk were consistent with the results of both in situ hybridization and 2-step PCR analysis (Table 2). Except for shrimp No. 4 , which gave a negative result, all dot blot results with hemolymph were likewise consis-
A.

\section{Dot blot-DNA}

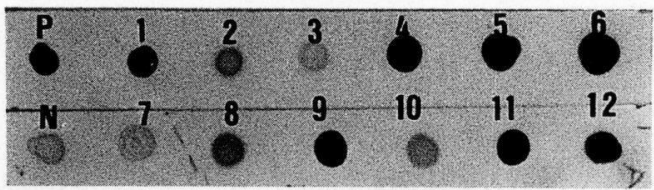

B.

Dot blot-tissue

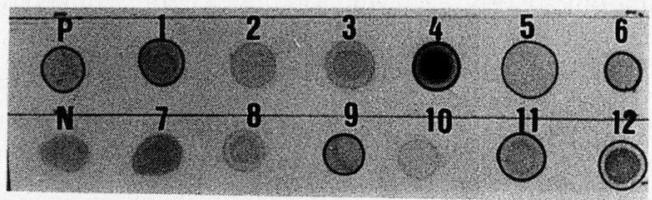

Fig. 1. Photograph of typical dot blot analysis results with positive $(\mathrm{P})$ and negative $(\mathrm{N})$ controls. (A): the results of dot blot using DNA from eyestalk. (B): the results of dot blot using homogenized eyestalk. The number identify the shrimp from which each sample was taken.

Table 2. Detection of WSBV in P. monodon from farms A and B by 2-step PCR, in situ hybridization and dot blot analysis using DNA or tissue homogenate

\begin{tabular}{|c|c|c|c|c|c|c|c|c|c|c|c|c|c|c|c|}
\hline \multirow{2}{*}{$\begin{array}{l}\text { Source of } \\
\text { shrimp }\end{array}$} & \multirow{2}{*}{$\begin{array}{l}\text { Date of } \\
\text { collection }\end{array}$} & \multirow{2}{*}{$\begin{array}{l}\text { Shrimp } \\
\text { number }\end{array}$} & \multirow{2}{*}{$\begin{array}{l}\text { White } \\
\text { spot }\end{array}$} & \multicolumn{3}{|c|}{$\operatorname{PCR}(1 / 2)^{\mathrm{a}}$} & \multicolumn{2}{|c|}{ In situ } & \multicolumn{3}{|c|}{ Dot blot-DNA } & \multicolumn{4}{|c|}{ Dot blot-tissue } \\
\hline & & & & $\mathrm{G}^{\mathrm{b}}$ & $\mathrm{P}^{\mathrm{b}}$ & $\mathrm{E}^{\mathrm{b}}$ & G & $\mathrm{P}$ & G & $\mathrm{P}$ & $\mathrm{E}$ & G & $\mathrm{P}$ & $\mathrm{E}$ & $\mathrm{H}^{\mathrm{b}}$ \\
\hline \multirow{10}{*}{ Farm A } & \multirow{10}{*}{ July 8} & 1 & + & $+/+$ & $+/+$ & $+1+$ & + & + & + & + & + & + & + & + & + \\
\hline & & 2 & + & $+/+$ & $+/+$ & $+/+$ & + & + & + & + & + & + & + & + & + \\
\hline & & 3 & + & $+/+$ & $+/+$ & $+/+$ & + & + & + & + & + & + & + & + & + \\
\hline & & 4 & - & $-1+$ & $-1+$ & $-1+$ & + & + & + & + & + & + & + & + & - \\
\hline & & 5 & - & $-1-$ & $-1-$ & $-1-$ & - & - & - & - & - & - & - & - & - \\
\hline & & 6 & - & $-1-$ & $-1-$ & $-1-$ & - & - & - & - & - & - & - & - & - \\
\hline & & 7 & + & $+/+$ & $+/+$ & $-1+$ & + & + & + & + & + & + & + & + & + \\
\hline & & 8 & + & $+/+$ & $-1+$ & $+/+$ & + & + & + & + & + & + & + & + & + \\
\hline & & 9 & - & $+1+$ & $+1+$ & $\mathrm{ND}^{\mathrm{c}}$ & + & + & + & + & ND & + & + & + & + \\
\hline & & 10 & + & $+1+$ & $+1+$ & ND & + & + & + & + & ND & + & + & + & + \\
\hline \multirow{11}{*}{ Farm B } & \multirow{11}{*}{ July 20} & 1 & + & $+/+$ & $+/+$ & $+1+$ & + & + & + & + & + & + & + & + & + \\
\hline & & 2 & + & $+/+$ & $+/+$ & $+1+$ & + & + & + & + & + & + & + & + & + \\
\hline & & 3 & - & $-1-$ & $-1-$ & $-1-$ & - & - & - & - & - & - & - & - & - \\
\hline & & 4 & - & $-1+$ & $+1+$ & $+1+$ & + & + & - & + & + & - & + & + & + \\
\hline & & 5 & + & $-1+$ & $-1+$ & $+1+$ & + & + & + & - & + & + & - & + & - \\
\hline & & 6 & + & $-1+$ & $-1+$ & $+/+$ & + & + & + & + & + & + & + & + & + \\
\hline & & 7 & + & $+/+$ & $+/+$ & $+1+$ & + & + & + & + & + & + & + & + & + \\
\hline & & 8 & - & $-1-$ & $-1-$ & $-1-$ & - & - & - & - & - & - & - & - & - \\
\hline & & 9 & - & $-1+$ & $-1+$ & $-1-$ & + & + & - & - & - & - & - & - & - \\
\hline & & 10 & - & $-1-$ & $-1-$ & $-1-$ & - & - & - & - & - & - & - & - & - \\
\hline & & 11 & - & $-1+$ & $-1+$ & $-1+$ & + & + & + & + & + & + & + & + & $\mathrm{ND}^{\mathrm{c}}$ \\
\hline \multirow{2}{*}{$\begin{array}{l}\text { Farm A N } \\
\text { Farm B }\end{array}$} & o. of positive & 10 & 6 & $7 / 8$ & $6 / 8$ & $4 / 6^{\mathrm{d}}$ & 8 & 8 & 8 & 8 & $6^{d}$ & 8 & 8 & 8 & 7 \\
\hline & shrimp & 11 & 5 & $3 / 8$ & $4 / 8$ & $6 / 7$ & 8 & 8 & 6 & 6 & 7 & 6 & 6 & 7 & $5^{e}$ \\
\hline
\end{tabular}

a: 1-step PCR result/2-step PCR result. d: Two samples were not determined. b: G: gill; P: pleopod; E: eye stalk; H: hemolymph.

e: One sample was not determined c: ND: not determined. 
tent. Dot blots with DNA and tissue homogenates detected WSBV in shrimps Nos. 4 and 9 even though these shrimps were not clinically diagnosed as having white spot syndrome, and shrimp No. 4 was even 1-step PCR negative. The pleopod of shrimp No. 8 was also only 2-step PCR positive but again WSBV was detected in this organ by both dot blot tests. Dot blot positive/ negative determinations were identical after $1 \mathrm{~h}, 2 \mathrm{~h}$ and $4 \mathrm{~h}$ development, although the intensity of the color reaction deepened over time (data not shown).

\section{Detection of WSBV in shrimp from farm $B$}

The 11 shrimp sampled from farm B were collected shortly after this farm had reported the death of a few of its shrimp from white spot disease. Five of these 11 shrimp had white spot syndrome in a mild form, while the other 6 looked healthy. The results of 2-step PCR, in situ hybridization and dot blots using DNA or tissue homogenate were again consistent, with the exception of the following 2-step PCR positive (1-step negative) organs: dot blotting failed to detected WSBV in the extracted DNA and homogenized tissue of gill from shrimp No. 4; the dot blot tests on the pleopod of shrimp

Table 3. Detection of WSBV in artificially infected $P$. monodon by 2-step PCR, in situ hybridization, and dot blot analysis using DNA or tissue homogenate

\begin{tabular}{|c|c|c|c|c|c|c|c|c|c|c|}
\hline \multirow{2}{*}{$\begin{array}{l}\text { Hours post } \\
\text { infection }\end{array}$} & \multirow{2}{*}{$\begin{array}{c}\text { Shrimp group } \\
\text { number }\end{array}$} & \multirow{2}{*}{$\begin{array}{l}\text { White } \\
\text { spot }\end{array}$} & \multicolumn{2}{|c|}{$\operatorname{PCR}(1 / 2)^{\mathrm{a}}$} & \multirow{2}{*}{$\frac{\text { In situ }}{G}$} & \multicolumn{2}{|c|}{ Dot blot-DNA } & \multicolumn{3}{|c|}{ Dot blot-tissue } \\
\hline & & & $G^{b}$ & $\mathrm{E}^{\mathrm{b}}$ & & G & $\mathrm{E}$ & $\mathrm{G}$ & $\mathrm{E}$ & $\mathrm{H}^{\mathrm{b}}$ \\
\hline \multirow{6}{*}{0} & $\mathrm{~S} 1$ & - & $-1-$ & $-1-$ & - & - & - & - & - & - \\
\hline & S2 & - & $-1-$ & $-1-$ & - & - & - & - & - & - \\
\hline & S3 & - & $-1-$ & $-1-$ & - & - & - & - & - & - \\
\hline & S4 & - & $-1-$ & $-1-$ & - & - & - & - & - & - \\
\hline & S5 & - & $-1-$ & $-1-$ & - & - & - & - & - & - \\
\hline & S6 & - & $-1-$ & $-1-$ & - & - & - & - & - & - \\
\hline \multirow{6}{*}{20} & $\mathrm{~S} 1$ & - & $+/+$ & $-1+$ & + & + & + & + & + & + \\
\hline & $\mathrm{S} 2$ & - & $-1-$ & $-1-$ & - & - & - & - & - & - \\
\hline & S3 & - & $+1+$ & $+/+$ & + & + & + & + & + & + \\
\hline & S4 & - & $-1-$ & $-1-$ & - & - & - & - & - & - \\
\hline & S5 & - & $-1+$ & $-1+$ & + & + & + & + & + & - \\
\hline & S6 & - & $-1+$ & $-1-$ & + & - & - & - & - & - \\
\hline \multirow{6}{*}{45} & $\mathrm{~S} 1$ & - & $-1+$ & $-1+$ & + & - & + & - & + & - \\
\hline & S2 & - & $-1+$ & $-1+$ & + & + & + & + & + & + \\
\hline & S3 & - & $+/+$ & $+1+$ & + & + & + & + & + & + \\
\hline & S4 & - & $-1-$ & $-1-$ & - & - & - & - & - & - \\
\hline & S5 & - & $+/+$ & $-1+$ & + & + & + & + & + & + \\
\hline & S6 & - & $+/+$ & $+1+$ & + & + & + & + & + & + \\
\hline \multirow{6}{*}{68} & S1 & - & $+/+$ & $+1+$ & + & + & + & + & + & + \\
\hline & S2 & - & $+/+$ & $+/+$ & + & + & + & + & + & + \\
\hline & S3 & - & $+/+$ & $+/+$ & + & + & + & + & + & + \\
\hline & S4 & - & $-1-$ & $-1-$ & - & - & - & - & - & - \\
\hline & S5 & - & $+/+$ & $+/+$ & + & + & + & + & + & + \\
\hline & S6 & - & $-1+$ & $+/+$ & + & + & + & + & + & $\mathrm{ND}^{\mathrm{c}}$ \\
\hline \multirow{6}{*}{96} & $\mathrm{~S} 1$ & - & $+1+$ & $+/+$ & + & + & + & + & + & + \\
\hline & $\mathrm{S} 2$ & - & $+/+$ & $-1+$ & + & + & + & + & + & + \\
\hline & S3 & - & $-1+$ & $+/+$ & + & + & + & + & + & + \\
\hline & S4 & - & $+/+$ & $+/+$ & + & + & + & + & + & + \\
\hline & S5 & - & $+/+$ & $+/+$ & + & + & + & + & + & + \\
\hline & S6 & - & $-1+$ & $+/+$ & + & + & + & + & + & + \\
\hline
\end{tabular}

a: 1-step PCR results/2-step PCR result.

b: G: gill; P: pleopod; E: eye stalk; H: hemolymph.

c: ND: not determined. 
No. 5 were also both false negative; both the gill and pleopod of shrimp No. 9 also gave false negatives in both dot blot tests (Table2). Additionally dot blots using hemolymph failed to detect the presence of WSBV in shrimps Nos. 5 and 9 (Table2). As with the samples from farm A, increasing development time affected only the intensity of the color reaction, not the positive/negative diagnosis (data not shown).

\section{Detection of WSBV in artificially infected shrimp}

The results of WSBV detection in experimentally infected shrimp were shown in Table 3. At $20 \mathrm{~h}$ pi, dot blotting failed to detect the presence of WSBV in hemolymph of shrimp \# 5 and none of the dot blots detected WSBV in shrimp \# 6, although the gill was 2-step PCR positive and WSBV positive by in situ hybridization (Table 3). At $45 \mathrm{~h} \mathrm{pi}$, results were consistent except for shrimp \# 1. Dot blotting failed to detect WSBV in the gill of this specimen, and dot blotting using hemolymph was also negative (Table 3 ). At 68 and $96 \mathrm{~h}$ pi, all diagnostic methods gave identical results. As before, development time $(1,2$ or $4 \mathrm{~h}) \mathrm{did}$ not affect diagnosis (data not shown). The 15 control shrimps that were tested at $0,20,45,68$ and $96 \mathrm{~h}$ were all diagnosed as WSBV-negative by all of the tests (data not shown).

\section{Evaluation of the relative sensitivity and specificity of dot blot analysis in comparison with in situ hybridization}

A summary of the WSBV detection results for all 66 shrimp (including the 15 negative controls) is shown in Table 4. Specificity was $100 \%$, that is, dot blotting produced no false positives. The sensitivity was also high and reached $94 \%$ when the tested organ was the eyestalk. The predictive value of positive test results here (the probability of WSBV infection in an animal with a positive result) was $100 \%$. The predictive value of negative test results (the probability that an animal does not have WSBV infection when the test result is negative) was about $83 \%$ (30/36) - 94\% (30/32) except for the pleopods, where the 45 samples from artificial infection test were not included. The WSBV infection prevalence in this sample population was $54.5 \%$.

\section{Development of the quick dot blot analysis}

As Table 1 shows, with the exception of protocols 4 and 8 , the modified experimental protocols were no less sensitive than the positive control (column 1). Under protocols 4 and 8 , the intensity of the color reaction was weaker and the sensitivity was only about $1 / 10$ of the positive control. This suggested that the dot blot analysis procedure could be shortened and that only about four hours would be needed to finish a batch of samples.

\section{Discussion}

The early target organs of WSBV in $P$. monodon include the gill and cuticular epidermis (Chang et al. 1996) which explains why for any given shrimp, the WSBV prevalence in gill, pleopod and eyestalk was almost identical. Often, as in the case of potential brooders, non-lethal testing is desired. Although the eyestalk, pleopod, and hemolymph (which also had a high prevalence of WSBV in the infected shrimp; see Tables 2, $3 \& 4$ ) are all possible candidates for use in dot blot analysis. In Taiwan, where eyestalk albation is commonly used to induce egg maturation in broodstock in hatchery farms (Chen 1990), the ablated eyestalk (minus the compound eye) can conveniently be used to prepare the tissue homogenate. This also avoids the additional stress to the shrimp that would result from the removal of a pleopod or the collection of hemolymph.

Results of using DNA and tissue homogenate for dot blotting in this study were identical, although the color reaction was more intense and the contrast was greater when extracted DNA was used. With tissue homoge-

Table 4. Specificity and sensitivity of the dot blot analysis using DNA and tissue homogenate by comparison with the in situ hybridization. This table summaries the results in Tables 2 and 3

\begin{tabular}{ccccccc}
\hline \hline $\begin{array}{c}\text { Source of DNA or } \\
\text { tissue homogenate }\end{array}$ & $\begin{array}{c}\text { Total number of } \\
\text { shrimp tested }\end{array}$ & Positive & False positive & Negative & False negative & Sensitivity $^{\mathrm{b}}$ \\
\hline Gill & 66 & 32 & 0 & 30 & 4 & $32 / 36(89 \%)$ \\
Pleopod & 21 & 14 & 0 & 5 & 2 & $14 / 18(88 \%)$ \\
Eyestalk & 66 & $34^{\mathrm{a}}$ & 0 & 30 & 2 & $34 / 36(94 \%)$ \\
Hemoymph & 64 & 28 & 0 & 30 & 6 & $28 / 34(82 \%)$ \\
\hline
\end{tabular}

a: This figure includes 2 positive diagnoses based on the dot blot tissue homogenate test only.

b: Sensitivity was defined as number of positive by dot blotting/number of positive by in situ hybridization. 
nate, and especially with the eyestalk, there was always a trace of light red discoloration in the blots, evidently caused by the astacin in the cuticular epidermis. However, since a single extraction of the tissue homogenate with an equal volume of saturated phenol can remove this pigment and increase the intensity of the color reaction (data not shown). We recommend using tissue homogenate because it is faster (only $4-4.5 \mathrm{~h}$ was required for quick dot blot) and cheaper.

While the standard dot blot analysis requires more than $24 \mathrm{~h}$, the quick dot blot procedure developed in this study required only 4 to $41 / 2 \mathrm{~h}$ to get the results. Many steps in the standard dot blot analysis can be shortened and the baking step can even be omitted. The UV crosslinkage step was important and could not be excluded although it required only two min. Another key step was the hybridization step, which can be shortened to 2 $\mathrm{h}$ but not to $30 \mathrm{~min}$. Although the intensity of the color reaction was weaker when the hybridization step was shortened to $2 \mathrm{~h}$, the sensitivity was equal to that of the positive control. When we tried following all the steps of the standard dot blot procedure at RT (approximately 27 to $30^{\circ} \mathrm{C}$ ), we found that the test's sensitivity was unchanged (data not shown). This suggested that dot blotting is suitable for use in the field, where an incubator or temperature-controlled ovens would not usually be availabe.

Of the many diagnostic methods that have already been developed to detect WSBV infection, the two most sensitive are in situ hybridization and 2-step PCR (Chang et al., 1996; Lo et al., 1996a). However, both of these protocols are time consuming (at least $12 \mathrm{~h}$ for 2-step PCR and 2-3 days for in situ hybridization), complicated and probably too expensive for general use in hatchery farms. Dot blotting, however, is a relatively simple procedure, especially if tissue homogenate used. Furthermore, tissue homogenate and hemolymph produced false negatives only in a few very lightly infected samples. In view of its accuracy, sensitivity, specificity and convenience, we conclude that the dot blot analysis described here could be developed into an effective diagnostic kit for screening shrimp.

\section{Acknowledgments}

This work was supported by the National Science Council under Grant No. NSC87-2815-C-022-002-B and NSC87-2313-B-022-004, ROC.

\section{References}

Bell, T. A. and D. V. Lightner (1988): A Handbook of Normal Penaeid Shrimp Histology. World Aquaculture Society, Baton Rouge, Louisiana, USA, pp. 2-6.

Chang, P. S., H. C. Chen and Y. C. Wang (1998): Detection of white spot syndrome baculovirus (WSBV) in experimentally infected wild shrimps, crabs and lobsters by in situ hybridization. Aquaculture, (In press).

Chang, P. S., C. F. Lo, Y. C. Wang and G. H. Kou (1996): Identification of white spot syndrome associated baculovirus (WSBV) target organs in the shrimp Penaeus monodon by in situ hybridization. Dis. Aquat. Org., 27, 131-139.

Chen, L. C. (1990): Aquaculture in Taiwan. The Alden Press, Oxford, 153-159.

Chou, H. Y., C. Y. Huang, C. H. Wang, H. C. Chiang and C. F. Lo (1995): Pathogenicity of a baculovirus infection causing white spot syndrome in cultured penaeid shrimp in Taiwan. Dis. Aquat. Org., 23, 165-173.

Lightner, D. V., B. T. Poulos, L. Bruce, R. M. Redman, J. Mari and J. R. Bonami (1992): New developments in Penaeid virology: Application of biotechnology in research and disease diagnosis for shrimp viruses of concern in the Americas. In "Disease of Cultured Penaeid Shrimp in Asia and the United States." (ed. by W. Fulks and K. L. Main) The Oceanic Institute, Honolulu, Hawaii, pp. 233-253.

Lightner, D. V. (1996): A handbook of pathology and diagnostic procedures for diseases of penaeid shrimp. World Aquaculture Society, Baton Rouge, LA, Section 3.11.

Lo, C. F., J. H. Leu, C. H. Ho, C. H. Chen, S. E. Peng, Y. T. Chen, C. M. Chou, P. Y. Yeh, C. J. Huang, H. Y. Chou, C. H. Wang, and G. H. Kou (1996a): Detection of baculovirus associated with white spot syndrome (WSBV) in penaeid shrimps using polymerase chain reaction. Dis. Aquat. Org., 25, 133-141.

Lo, C. F., C. H. Ho, S. E. Peng, C. H. Chen, H. C. Hsu, Y. L. Chiu, C. F. Chang, K. F. Liu, M. S. Su, C. H. Wang and G. H. Kou (1996b): White spot syndrome baculovirus (WSBV) detected in cultured and captured shrimp, crabs and other arthropods. Dis Aquat. Org., 27, 215-225.

Lo, C. F., C. H. Ho, C. H. Chen, K. F. Liu, Y. L. Chiu,. P. Y. Yeh, S. E. Peng, H. C. Hsu, H. C. Liu, C. F. Chang,, M. S. Su, C. H. Wang and G. H Kou (1997): Detection and tissue tropism of white spot syndrome baculovirus (WSBV) in captured brooders of Penaeus monodon with a special emphasis on reproductive organs. Dis. Aquat. Org., 30, 53-72.

Mialhe, E., V. Boulo, E. Bachere, D. Hervio, K. Cousin, D. Noel, T. Noel, M. Ohesser, R. M. le Deuff, B. Despres and S. Gendreau (1992): Development of new methodologies for diagnosis of infectious diseases in mollusc and shrimp aquaculture. Aquaculture, 107, 155-164.

Vivares, C. P. and J. Guesdon (1992): Nucleic acid probes in aquatic bacteriology. Aquaculture, 107, 147-154.

Wang, C. H., C. F. Lo, J. H. Leu, C. M. Chou, P. Y. Yeh, H. Y. Chou, M. C. Tung, C. F. Chang, M. S. Su and G. H. Kou (1995): Purification and genomic analysis of baculovirus associated with white spot syndrome (WSBV) of Penaeus 
monodon. Dis. Aquat. Org., 23, 239-242.

Wang, Y. C., C. F. Lo, P. S. Chang and G. H. Kou (1998): Experimental infection of white spot baculovirus (WSBV) in some cultured and wild decapods in Taiwan. Aquaculture, (in press).

Wyban, J. A., J. S. Swingle, J. N Sweeney. and G. D. Pruder
(1992): Development and commercial performance of high health shrimp using specific pathogen free (SPF) broodstock Penaeus vannamei. In "Proceedings of the Special Session on Shrimp Farming” (ed. by James Wyban). pp. 254-260, World Aquaculture Society, Baton Rouge, Louisiana, USA. 